\title{
REGIONAL PORT DEVELOPMENT STRATEGIES: A CASE STUDY OF BRANTA PORT DEVELOPMENT
}

\author{
R. Aditya Jalasena Jiwandhono ${ }^{1}$, Bambang Triatmodjo ${ }^{2}$, Sigit Priyanto ${ }^{3}$ \\ Magister Sistem dan Teknik Transportasi, Universitas Gadjah Mada \\ Jl. Grafika No. 2 Kampus UGM, Yogyakarta 55281, Indonesia
}

\begin{abstract}
Branta Port, located in Pamekasan Madura, is a connecting port area around Java Island and Madura Island. The port has an important role in logistics and supply chain activities as well as economic development in Indonesia, especially in Java and Madura. But the reality is Branta Port has some shortcomings in the port facilities to security sector. It based on the lack of regulation enforcement of the port management itself. The lack of renewal of the port master plan is also one of the obstacles to the port's poor performance. Therefore, with this research, it is expected to obtain a broad picture of the development strategy at the Branta Port. The methods are Location Quotient (LQ) \& ships loading and discharge at port forecast using several forecasting analysis. The results show the ships call, loading and discharge flow at Branta Port have a fluctuating pattern follow the seasonal trends in salt production activities in Madura region. Where in 2039 (long-term) the loading and discharge flow at Branta Port is predicted to reach 380,927 tons which in 2018 amounted to 139,855 tons. The results of the port performance calculation are performed using port performance indicators called Berth Occupancy Ratio (BOR), where the BOR value from year to year to the long-term forecasting year (2039) is $22.08 \%$, which is still below $40 \%$ for an additional indicates that the jetty is not busy according to UNCTAD criteria. Whereas the need for port facilities such as warehouses and stacking fields has increased. The development strategy focused on port facilities such as the berth length expansion from $100 \mathrm{~m}$ to $186 \mathrm{~m}$, construction of port warehouses of $183 \mathrm{~m}^{2}$, improvement of several port facilities such as navigation facilities and causeways, also the addition of port waste treatment facilities.
\end{abstract}

Keywords: Location Quotient, forecasting, econometric method, Berth Occupancy Ratio

\section{INTRODUCTION.}

The development of logistics and supply chain activities in the world is growing time after time. The sea transportation sector is the largest contributor to logistics and supply chain activities all countries. As one of the countries that has a large share in sea transportation sector in Asia, Indonesia have various challenges and developments in sea transportation sector over time. However, the current development of ports which are mostly done by the government is still focused on the main port which have large market nationally to internationally. While some small ports such as regional ports and local feeder ports are still lacking in its development studies.

One of the regional feeder port in Indonesia that has great potential in its development is Port of Branta Pamekasan. The port is a class II port located in the village of Branta Pesisir, Tlanakan District, Madura. The Port of Branta serves the activity of loading and discharge of cargo ships consisting of various types of commodities, ranging from general goods to bulk. In addition, there are also docks that are used for inter-island crossing vessels around the Madura region. Ships usually carrying out salt and tobacco as potential sector around the port and also daily staple goods. The port has several port facilities such as a pier measuring $100 \times 10 \mathrm{~m}^{2}$, trestle, causeway, stacking field and guard post of the Republic of Indonesia Sea and Coast Guard or Kesatuan Penjagaan Laut dan Pantai Republik Indonesia (KPLP). This port does not have loading and unloading equipment, the activities carried out using ship cranes and using the services of TKBM (Loading and Unloading Workers).

Pettit and Beresford (2009) describe the role of different ports in terms of demand characteristics and port transitions from simple gateways to larger and more complex logistic (Pettit, 2009). The role of the port depends on the type of supply chain in operation as well as the overall characteristics of 
supply and demand. The characteristics of supply and demand determine how short-term and longterm planning can be used to facilitate resource use. Characteristics often depend on the uncertainty between different echelons as well as different types of products. Demand and supply can be seasonal, stochastic, sustainable or dependent (Slack, 2007). The different roles that ports can take depends on the characteristics of demand, which means that the port must provide different services depending on the nature of the supply chain, so it is very important for the port to determine how the port environment is configured for supply. chain. An example of the development of a strategic port is presented by Van den Berg and De Langen (2011) which shows the case of the Port of Barcelona in the Spanish region (Van den Berg, 2011).The Barcelona case is used because it shows how a port can move from being a gateway to a supply chain integrator, by improving infrastructure at the center of land and building distribution.

To determine the feasibility of a port, an assessment of the port itself is needed. One of the assessment of the port whether it is in accordance with the functions and interests of the port is port performance using port performance indicators. In a study by Kusuma (2010), port performance can be assessed using several indicators.

It's expected that the ships call will occur for the next 30 years, so the supporting sectors for port development in the area around the port can be identified. From the results of the study, the right strategy can be developed to develop the port.

\section{METHODOLOGY}

\subsection{Research Methods}

The research method used is the collection of data to the implementation of research using several analytical methods. At the data collection stage, the data was obtained from Branta Port Implementing Unit under the auspices of the Ministry of
Transportation which will be used as material to obtain results from port performance and development strategies that will be the objectives of the study. Data that will be needed in this research are ships call for the past 10 years, load and discharge flow during the last 10 years, port facilities, population data of Pamekasan Regency, natural resources data in Pamekasan Regency, and Pamekasan Gross Domestic Product (GDP). Data relating to the area of Pamekasan Madura was obtained from Badan Pusat Statistik (BPS) of Pamekasan Regency.

This research was carried out by several analytical processes which include services, facilities, equipments and also forecasting analysis. In conducting research, there are several research methods used. The forecasting methods used are linear trends, exponential trends, econometrics, and multiplicatives where the best and most fulfilling forecasting methods will be chosen. In addition, Location Quotient (LQ) analysis on Natural Resources (agriculture, animal husbandry and salt) is also carried out, which is the potential of port development which then continues to the port development needs.

\subsection{Location Quotient Analysis}

Location Quotient (LQ) is a term that we hear a lot when working in the area of economic development. Location Quotient (LQ) is a simple ratio used to determine the concentration or dominance of a particular industry in a region (i.e. Local Government area) in comparison to a larger reference or benchmark region (i.e. State or Nation). It is traditionally used to compare an industry share of regional employment, however it can also be used for other economic measures, such as value add, imports or exports.

The variables used in this calculation are GDP, economic sector, development of potential sectors. After that the results of the analysis are calculated to get the payload per tonne of the ship. 
In this study to identify the basis and nonbase sectors, namely by using the location quotient (LQ) technique with three criteria, namely $L Q>1, L Q$ $=1$ and $L Q>1$, using the following formula:

$$
L Q i j=\frac{X i j / R V j}{X i / R V}
$$

- LQij = Index / coefficient of Location I sector Quotient in district / city j

- $\mathrm{Xij}=$ Sector $\mathrm{i}$ GRDP in regencies / cities $\mathrm{j}$

- $\mathrm{Xi}=$ GRDP of sector $\mathrm{i}$ in the Province (reference)

- $R V j=$ Total district $/$ city GRDP $\mathrm{j}$

- $\mathrm{RV}=$ Total Provincial GRDP

\subsection{Forecasting Methods}

For the projection method, several methods are used including trend projection, econometric, and multiplicative. Trend projection is a time-series forecasting method that adjusts a trend line to a set of past data and then is projected in a line to predict the future for short-term or long-term forecasting.

The exponential method or exponential refinement (exponential smoothing) Exponential smoothing is a technique of forecasting moving averages with weighting where the data is weighted by an exponential function. Exponential smoothing is a method of forecasting moving averages with sophisticated weighting, but still easy to use. This method is not influenced by trends or seasons.

The making of econometrics models is one of econometric contributions in addition to making predictions (forecasting) and making various alternative decisions that are quantitative so that it can facilitate decision makers to make choices. One of the most important parts of econometrics is regression analysis. This analysis is used to determine the relationship between one variable with another variable. Based on the data used, econometrics is divided into three analyzes, namely time series analysis, inter-region analysis (cross section), and panel data analysis. The time series analysis explains the behavior of a variable over several consecutive times, in contrast to the analysis of inter-regions which explains between several regions at a particular time (snapshot). Meanwhile panel data analysis combines time series data with data between regions.

Forecasting using a multiplicative model is used if there is a tendency or sign that seasonal patterns depend on the size of the data. In other words, seasonal patterns enlarge as data size increases. The first is to do a logarithmic calculation. Where the logarithm is a mathematical operation which is a reversal of the exponent or departure with the basic formula $a c=b$, then $a \log b=c$. Then forecasting is done using quarter in accordance with the variable seasonal time.

\subsection{Berth Occupancy Ratio (BOR)}

Quoted from a book titled "Port Planning" by Prof. Dr. Ir. Bambang Triatmodjo, BOR (Berth Occupancy Ratio) or the level of use of the pier is a comparison between the time of the use of the pier and the time available within a certain time period expressed in percentage. BOR values can be calculated using calculations that have been set by UNCTAD (United Nations Conference on Trade and Development) of the United Nations in the port performance indicators report. BOR values can be calculated using several equations that depend on the number and type of terminations (Triatmodjo, 2009).

$B O R=\frac{V s \times \text { St }}{\text { effective time } \times n} \times 100 \%$

- BOR : Berth Occupancy Ratio (\%)

- Vs : Number of ships served (units / year)

- St : Service time (hours / day)

- $\mathrm{N} \quad$ : Number of terminations

- Effective time : Number of days in a year 


\subsection{Berth Throughput (BTP)}

Berth Throughput is the total tonnage of cargo handled at the pier divided by the total amount of cargo tonnage from the berth. The value of Berth Throughput can be formulated as follows.

$B T P=\frac{H B O R J G P}{L 1}$

- BTP : Berth Throughput ( $m$, tons, boxes or TEUs / $\mathrm{m}$ / year)

- $\mathrm{H} \quad$ : Number of working days in a year (days)

- BOR : Berth Occupancy Ratio (\%)

- A : Working hours per day

- G : Number of gang at a time

- P : Productivity (m3, tonnes, box or TEUs / hours)

- L1 : Berth length for one ship (berth)

\section{RESULT AND DISCUSSION.}

\subsection{Location Quotient (LQ) Analysis}

Location Quotient (LQ) analysis is performed to obtain the level of specialization of economic sectors in an area that utilizes a base sector or leading sector. Socioeconomic indicators used in the projected volume of goods are GRDP (Gross Regional Domestic Product) and population in the hinterland region.

This analysis is used to determine the extent of specialization of economic sectors in a region or any sector that is a base sector or leading sector.

Table 1. Location Quotient (LQ) Analysis Results in Pamekasan Regency

\begin{tabular}{|c|l|c|}
\hline No & \multicolumn{1}{|c|}{ Business field } & $\begin{array}{c}\text { Average } \\
\text { LQ }\end{array}$ \\
\hline 1 & $\begin{array}{l}\text { Agriculture, Livestock, Forestry \& } \\
\text { Fisheries }\end{array}$ & 2,72 \\
\hline 2 & Mining and excavation & 0,68 \\
\hline 3 & Processing industry & 0,22 \\
\hline 4 & Electricity and Gas & 0,19 \\
\hline 5 & Water \& Waste Management & 0,91 \\
\hline 6 & Construction & 1,14 \\
\hline 7 & Automotive Provider & 1,16 \\
\hline 8 & Transportation and Warehousing & 0,57 \\
\hline 9 & Accommodation \& Foods & 0,13 \\
\hline 10 & Information and Communication & 1,31 \\
\hline 11 & Financial Services and Insurance & 0,73 \\
\hline
\end{tabular}

\begin{tabular}{|c|l|c|}
\hline No & \multicolumn{1}{|c|}{ Business field } & $\begin{array}{c}\text { Average } \\
\text { IO }\end{array}$ \\
\hline 12 & Real Estate & 1,15 \\
\hline 13 & Company Services & 0,55 \\
\hline 14 & Government administration & 3,06 \\
\hline 15 & Educational Services & 1,68 \\
\hline 16 & Health \& Social Activities & 1,16 \\
\hline 17 & Other Services & 0,82 \\
\hline
\end{tabular}

From the table above, it can be seen that there are 8 (eight) sectors that get LQ results> 1 . The largest sector is the government administration sector, while the second largest sector is the agriculture, livestock, forestry and fisheries sectors which have an average value of LQ 2, 7239 .

Table 2. Business Sector Contribution to GRDP Value (\%)

\begin{tabular}{|r|l|r|}
\hline No & \multicolumn{1}{|c|}{ Business field } & $\begin{array}{c}\text { Contribution } \\
\text { (\%) }\end{array}$ \\
\hline 1 & $\begin{array}{l}\text { Agriculture, Livestock, } \\
\text { Forestry \& Fisheries }\end{array}$ & 31,40 \\
\hline 2 & Mining and excavation & 3,56 \\
\hline 3 & Processing industry & 6,29 \\
\hline 4 & Electricity and Gas & 0,06 \\
\hline 5 & Water \& Waste & 0,09 \\
\hline 6 & Management & 10,39 \\
\hline 7 & Automotive Provider & 21,08 \\
\hline 8 & Transportation and & 1,67 \\
\hline 9 & Warehousing & 0,65 \\
\hline 10 & Information and & 7,34 \\
\hline 11 & Communication & $\begin{array}{l}\text { Financial Services and } \\
\text { Insurance }\end{array}$ \\
\hline 12 & Real Estate & 1,88 \\
\hline 13 & Company Services & 1,97 \\
\hline 14 & Government administration & 0,42 \\
\hline 15 & Educational Services & 6,82 \\
\hline 16 & Health \& Social Activities & 4,43 \\
\hline 17 & Other Services & 0,76 \\
\hline & PDRB ADHK & 1,19 \\
\hline
\end{tabular}

Furthermore, the contribution of each leading sector which has a base sector or leading sector is calculated in the Pamekasan Regency. Where do the calculation of the contribution of these sectors to the area of East Java Province.

Table 3. Calculation Results of Leading Sector Contribution to East Java Province

\begin{tabular}{|c|l|r|}
\hline No & \multicolumn{1}{|c|}{ Sector } & $\begin{array}{c}\text { Contribution } \\
(\%)\end{array}$ \\
\hline 1 & Cow Livestock & 4,02 \\
\hline 2 & Goat Livestock & 2,00 \\
\hline 3 & Rice Production & 0,87 \\
\hline
\end{tabular}




\begin{tabular}{|c|l|c|}
\hline No & \multicolumn{1}{|c|}{ Sector } & $\begin{array}{c}\text { Contribution } \\
(\%)\end{array}$ \\
\hline 4 & Salt Production & 30,57 \\
\hline 5 & $\begin{array}{l}\text { Tobacco } \\
\text { Production }\end{array}$ & 15,13 \\
\hline
\end{tabular}

From the calculation above, it can be seen that the largest contribution of the leading sector in the Pamekasan region to the Province of East Java is the salt production sector. Wherein it is known that the contribution of the salt production sector is $30.57 \%$.

\subsection{Branta Port Services Forecast}

The services provided by the Port will influence the supporting facilities available at the Port as well as measuring the performance, therefore data records are needed to measure how effective and efficient the facilities are used for operations from time to time. Therefore it is necessary to calculate the forecasting of port services. The calculation is a calculation of the ship visits and also the loading and unloading flow at the port. Forecasting methods are trend (linear \& exponential) method, the econometric method, and the multiplicative method.

\subsubsection{Ship Call Forecast}

From the recapitulation of the deviation and $R$ Square calculation results of the forecasting methods, the chosen method is obtained using a multiplicative model. Where the multiplicative model is used in accordance with the decision or the sign in accordance with the data. In other words, data is transferred. The multiplicative model used is a model with some variables such as ship call flow $(\mathrm{Y})$, load and discharge flow (X1), population of Pamekasan Regency (X2), GRDP of Pamekasan Regency (X3), and salt production (X4) which is the result of the selected variable from the results of the Location Quotient (LQ) analysis. Where the result of the deviation is 1,001 and the $R^{2}$ is 0,848 .
Table 4. Multiplicative Calculation Results of Ship Call

\begin{tabular}{|c|c|c|c|}
\hline \multirow{2}{*}{ No } & \multirow{2}{*}{ Year } & Forecast $(\mathrm{Y})$ & \multirow{2}{*}{ Log } \\
\hline & & $(\mathrm{X} 1, \mathrm{X} 2, \mathrm{X} 3, \mathrm{X} 4)$ & \\
\hline 1 & 2010 & 777 & 2,891 \\
\hline 2 & 2011 & 848 & 2,928 \\
\hline 3 & 2012 & 1.096 & 3.040 \\
\hline 4 & 2013 & 1.138 & 3,056 \\
\hline 5 & 2014 & 1.211 & 3,083 \\
\hline 6 & 2015 & 1.400 & 3,146 \\
\hline 7 & 2016 & 1.486 & 3,172 \\
\hline 8 & 2017 & 1.523 & 3,183 \\
\hline 9 & 2018 & 1.574 & 3,197 \\
\hline
\end{tabular}

\begin{tabular}{|l|r|}
\hline \multicolumn{2}{|c|}{ Regression Statistics } \\
\hline Multiple R & 0,921 \\
\hline R Square & 0,848 \\
\hline Adjusted R Square & 0,696 \\
\hline Standard Error & 0,066 \\
\hline Observations & 9,000 \\
\hline
\end{tabular}

From the forecast result using the multiplicative model, the value of $R^{2} 0.848$ obtained and generate the equation of $Y=82.009-0.154 X 1$ $14.983 \times 2+2.703 \times 3-0.0653 \times 4$.

From these results forecasting is done using a multiplicative model with related variables. The model considers trends and also seasonal from fluctuating ship arrival data.

Table 5. Ships Call Forecasting Results

\begin{tabular}{cc|cc|cc}
\hline Year & $\begin{array}{c}\text { Ships } \\
\text { Call } \\
\text { (Unit) }\end{array}$ & Year & $\begin{array}{c}\text { Ships } \\
\text { Call } \\
\text { (Unit) }\end{array}$ & Year & $\begin{array}{c}\text { Ships } \\
\text { Call } \\
\text { (Unit) }\end{array}$ \\
\hline \hline 2019 & 1.856 & 2026 & 2.988 & 2033 & 3.792 \\
2020 & 2.190 & 2027 & 3.020 & 2034 & 3.653 \\
2021 & 2.248 & 2028 & 2.934 & 2035 & 4.183 \\
2022 & 2.215 & 2029 & 3.386 & 2036 & 4.177 \\
2023 & 2.589 & 2030 & 3.406 & 2037 & 4.013 \\
2024 & 2.634 & 2031 & 3.294 & 2038 & 4.582 \\
2025 & 2.575 & 2032 & 3.785 & 2039 & 4.563 \\
\hline \hline
\end{tabular}

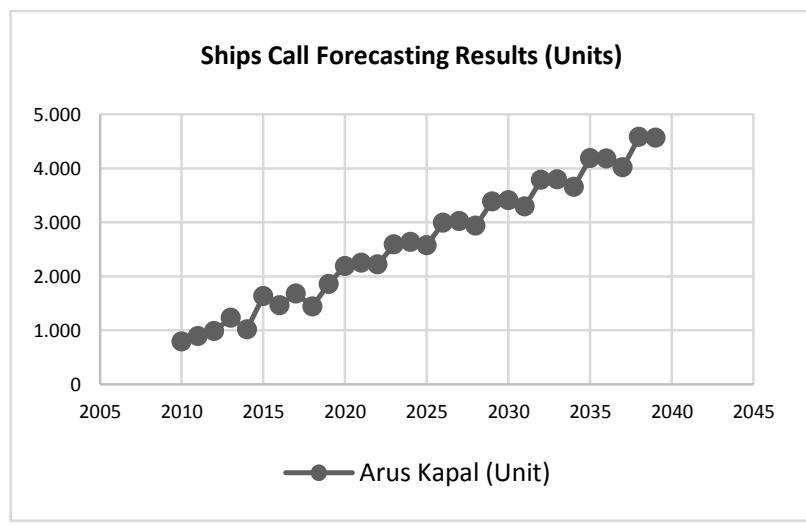

Fig.1 Ships Call Forecasting Chart 
From the table and graph above, it can be seen that in 2039, the estimated arrival of vessels at the Branta Pamekasan Regional Port are 4,563 ships.

\subsubsection{Port Load \& Discharge Forecast}

From the recapitulation of the deviation and $\mathrm{R}$ Square calculation results of the forecasting methods, the chosen method is obtained using a multiplicative model. Where the multiplicative model is used in accordance with the decision or the sign in accordance with the data. In other words, data is transferred. The multiplicative model used is a model with some variables such as load and discharge flow $(\mathrm{Y})$, ships call $(\mathrm{X} 1)$, population of Pamekasan Regency (X2), GRDP of Pamekasan Regency (X3), and salt production (X4) which is the result of the selected variable from the results of the Location Quotient (LQ) analysis. Where the result of the deviation is 1,437 and the $R^{2}$ is 0,669 .

Table 6. Multiplicative Calculation Result of Load \& Discharge Flow

\begin{tabular}{|c|c|c|c|}
\hline \multirow{2}{*}{ No } & \multirow{2}{*}{ Tahun } & Forecast $(\mathrm{Y})$ & \multirow{2}{*}{ Log } \\
\hline & & $(\mathrm{X} 1, \mathrm{X} 2, \mathrm{X} 3, \mathrm{X} 4)$ & \\
\hline 1 & 2010 & 99.086 & 4,996 \\
\hline 2 & 2011 & 162.222 & 5,210 \\
\hline 3 & 2012 & 205.901 & 5,314 \\
\hline 4 & 2013 & 204.447 & 5,311 \\
\hline 5 & 2014 & 225.886 & 5,354 \\
\hline 6 & 2015 & 202.196 & 5,306 \\
\hline 7 & 2016 & 251.933 & 5,401 \\
\hline 8 & 2017 & 122.734 & 5,089 \\
\hline 9 & 2018 & 136.333 & 5,135 \\
\hline
\end{tabular}

\begin{tabular}{|l|r|}
\hline \multicolumn{2}{|c|}{ Regression Statistics } \\
\hline Multiple R & 0,818 \\
\hline R Square & 0,669 \\
\hline Adjusted R Square & 0,338 \\
\hline Standard Error & 0,135 \\
\hline Observations & 9,000 \\
\hline
\end{tabular}

From the forecast result using the multiplicative model, the value of $R^{2} 0,669$ obtained and generate the equation of $Y=316,481-0,6413 X 1$ $-57,216$ X2 +7,606 X3-0,247 X4.

From these result, forecasting is done using a multiplicative model with related variables. The model considers trends and also seasonal from fluctuating load \& discharge flow.
Table 7. Load \& Discharge Flow Forecasting Result

\begin{tabular}{|c|c|c|c|c|c|}
\hline Year & $\begin{array}{c}\text { Load \& } \\
\text { Disch. } \\
\text { (Ton) }\end{array}$ & Year & $\begin{array}{c}\text { Load \& } \\
\text { Disch. } \\
\text { (Ton) }\end{array}$ & Year & $\begin{array}{c}\text { Load \& } \\
\text { Disch. } \\
\text { (Ton) }\end{array}$ \\
\hline 2019 & 194.469 & 2026 & 251.875 & 2033 & 349.974 \\
\hline 2020 & 227.035 & 2027 & 319.022 & 2034 & 248.648 \\
\hline 2021 & 288.069 & 2028 & 226.976 & 2035 & 289.134 \\
\hline 2022 & 205.304 & 2029 & 264.294 & 2036 & 365.451 \\
\hline 2023 & 239.455 & 2030 & 334.498 & 2037 & 259.483 \\
\hline 2024 & 303.546 & 2031 & 237.812 & 2038 & 301.553 \\
\hline 2025 & 216.140 & 2032 & 276.714 & 2039 & 380.927 \\
\hline
\end{tabular}

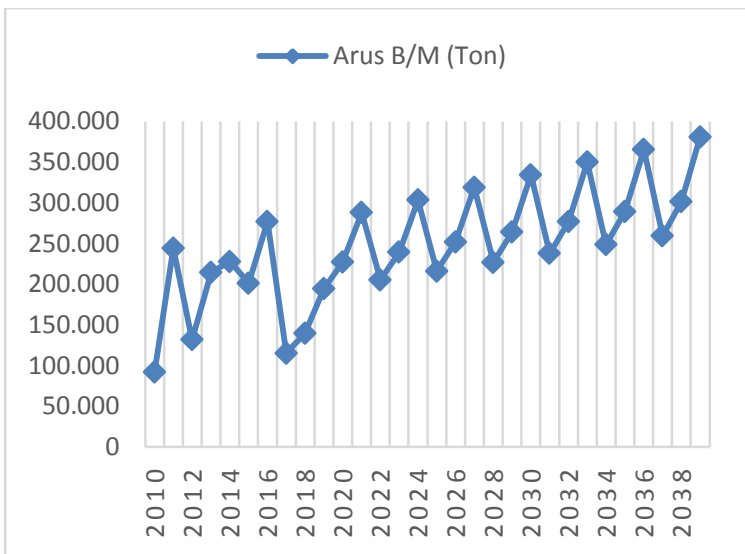

Fig.2 Load \& Discharge Flow Forecasting Result Chart

From the table and graph above, it can be seen that in 2039, the estimated loading and unloading of goods at the Branta Pamekasan Regional Port is 380,927 tons.

\subsection{Port Facility Requirements Analysis}

In this section, an analysis of the facilities requirements at Branta Port will be calculated. The analysis is processed from the forecasting data of ship arrival flows and also the loading and unloading of goods at the Port of Branta.

\subsubsection{Berth Requirements Analysis}

As a determination of the berth requirements analysis, forecasting data from the two variables are given, the ships call and the loading and unloading flow using the multiplicative forecasting method. Where the dependent variable $(Y)$ is compared to the four independent variables $\mathrm{X} 1, \mathrm{X} 2, \mathrm{X} 3, \& \mathrm{X} 4$.

Then the Branta Port's pier needs to be calculated using a number of equations to determine the port's performance, namely BOR as the port usage level and Berth Throughput or total tonnage 
of cargo handled at the pier divided by the total number of cargo tonnages from the berth.

Table 8. Berth Requirements Result

\begin{tabular}{|c|c|c|c|c|}
\hline Year & $\begin{array}{c}\text { Load \& } \\
\text { Discharge } \\
\text { (tons) }\end{array}$ & $\begin{array}{c}\text { BOR } \\
\text { (\%) }\end{array}$ & $\begin{array}{c}\text { BTP } \\
\text { (m3 } \\
\text { ton) }\end{array}$ & $\begin{array}{c}\text { Berth } \\
\text { Length } \\
\text { Analysis } \\
\text { (m) }\end{array}$ \\
\hline 2019 & $194.468,63$ & 16,91 & 965,03 & 201,51 \\
\hline 2020 & $227.035,19$ & 19,74 & 965,03 & 235,26 \\
\hline 2021 & $288.069,21$ & 16,70 & $1.447,55$ & 199,00 \\
\hline 2022 & $205.304,41$ & 11,90 & $1.628,50$ & 126,07 \\
\hline 2023 & $239.454,90$ & 13,88 & $1.628,50$ & 147,04 \\
\hline 2024 & $303.545,52$ & 17,60 & $1.628,50$ & 186,40 \\
\hline 2025 & $216.140,19$ & 12,53 & $1.628,50$ & 132,72 \\
\hline 2026 & $251.874,62$ & 14,60 & $1.628,50$ & 154,67 \\
\hline 2027 & $319.021,83$ & 18,49 & $1.899,91$ & 167,91 \\
\hline 2028 & $226.975,98$ & 13,16 & $1.899,91$ & 119,47 \\
\hline 2029 & $264.294,33$ & 15,32 & $1.899,91$ & 139,11 \\
\hline 2030 & $334.498,13$ & 19,39 & $1.899,91$ & 176,06 \\
\hline 2031 & $237.811,76$ & 13,79 & $1.899,91$ & 125,17 \\
\hline 2032 & $276.714,04$ & 16,04 & $1.899,91$ & 145,65 \\
\hline 2033 & $349.974,44$ & 20,29 & $1.899,91$ & 184,21 \\
\hline 2034 & $248.647,54$ & 14,41 & $1.899,91$ & 130,87 \\
\hline 2035 & $289.133,76$ & 16,76 & $1.899,91$ & 152,18 \\
\hline 2036 & $365.450,75$ & 21,19 & $1.899,91$ & 192,35 \\
\hline 2037 & $259.483,32$ & 15,04 & $1.899,91$ & 136,58 \\
\hline 2038 & $301.553,47$ & 17,48 & $1.899,91$ & 158,72 \\
\hline 2039 & $380.927,06$ & 22,08 & $1.899,91$ & 200,50 \\
\hline & & & & \\
\hline
\end{tabular}

From the table above, it can be seen that the calculation results determine the performance and dimensions of the Branta Port pier that have been available and that must be developed to meet future needs. Where the results obtained Berth Occupancy Ratio (BOR) in short-term forecasting (2024) of $17.597 \%$, medium-term (2024) of $15.32 \%$, and Long-term (2039) of $22.08 \%$. From the results of these calculations it can be seen that the BOR value is below $40 \%$ for an additional indicating that the use of the dock is not busy according to UNCTAD criteria. From the calculation results it can be stated that for the development of the Branta Port pier, it is still able to serve the needs in the future, but judging by the results of the forecasting of loading and unloading flow and the arrival of ships in the Branta Port which are rising every year, the calculation of the berth analysis also increases from year to year. So that the development is still needed to be developed at the Branta Port pier.

\subsubsection{Warehouse \& Cargo Yard Requirement}

Port of Branta does not have a warehouse as a place to store commodities to be shipped. In addition, cargo yard at the Port of Branta also does not meet the criteria. Calculation of warehouse are obtained using several equations adapted from the Port Planning book by Prof. Bambang Triatmodjo.

$A=\frac{\operatorname{Tr} T S f}{365 \operatorname{Sth}(1-B S)}$

- $\mathrm{T} \quad$ : Throughput per year (tons)

- TrT : Transit time / dwelling time (days)

- Sf : Storage factor (average volume for unit weight of commodity, m3 / ton)

- Sth : Stacking height (height of the load stack, $\mathrm{m})$

\section{- BS : Broken Stowage}

Assumptions of some values in the above equation is made to get the required area. Some of these assumptions are that goods stored in Branta Port warehouse account for $10 \%$ of the total load throughput, while those stored in the stock yard are $5 \%$ of the total cargo throughput for a year. Besides the other assumptions are the transit time or dwelling time is given at 7 (seven) days, storage factor at 0.5 , and broken stowage at 0.5 .

Table 9. Warehouse Requirement Calculation Result

\begin{tabular}{|r|c|r|r|}
\hline \multicolumn{4}{|c|}{ Warehouse Area } \\
\hline Year & T (Tons) & $\begin{array}{c}\text { Goods Stored } \\
(\text { Ton) }\end{array}$ & $\begin{array}{c}\text { A } \\
\left(\mathbf{m}^{\mathbf{2}}\right)\end{array}$ \\
\hline 2019 & $194.468,63$ & $19.446,86$ & 93 \\
\hline 2024 & $303.545,52$ & $30.354,55$ & 146 \\
\hline 2029 & $264.294,33$ & $26.429,43$ & 127 \\
\hline 2039 & $380.927,06$ & $38.092,71$ & 183 \\
\hline
\end{tabular}

Table 10. Cargo Yard Requirement Calculation Result

\begin{tabular}{|c|c|c|c|}
\hline \multicolumn{4}{|c|}{ Cargo Yard } \\
\hline Year & $\mathbf{T}$ (Ton) & $\begin{array}{c}\text { Cargo Stored } \\
\text { (Ton) }\end{array}$ & A (m2) \\
\hline 2019 & $194.468,63$ & $9.723,43$ & 47 \\
\hline 2024 & $303.545,52$ & $15.177,28$ & 73 \\
\hline 2029 & $264.294,33$ & $13.214,72$ & 63 \\
\hline 2039 & $380.927,06$ & $19.046,35$ & 91 \\
\hline
\end{tabular}




\subsection{Navigation Channels and Basins Analysis}

The equations to get the area of water based on Technical Standards for Port and Harbour Facilities OCDI (The Overseas Coastal Area Development Institute of Japan 1999), the results of the calculation of water area requirements at Branta Harbor are obtained. The calculation results can be seen in the table below.

Table 11. Navigation Channels and Basins

\begin{tabular}{|c|l|c|c|}
\hline Ro & Requirements & Formula & Result \\
\hline 1 & $\begin{array}{l}\text { Anchorage } \\
\text { Area }\end{array}$ & $\mathrm{R}=\mathrm{L}+6 \mathrm{D}+30 \mathrm{~m}$ & $171,8 \mathrm{~m}$ \\
\hline 2 & $\begin{array}{l}\text { Navigation } \\
\text { Channels depth }\end{array}$ & $\begin{array}{l}\mathrm{H}= \\
\mathrm{d}+\mathrm{G}+\mathrm{R}+\mathrm{P}+\mathrm{S}+\mathrm{K}\end{array}$ & $10,3 \mathrm{~m}$ \\
\hline 3 & $\begin{array}{l}\text { Navigation } \\
\text { Channels width }\end{array}$ & $\mathrm{LoA}$ & $104 \mathrm{~m}$ \\
\hline 4 & $\begin{array}{l}\text { Mooring Basin } \\
\text { Area }\end{array}$ & $1,5 \times \mathrm{LoA}$ & $156 \mathrm{~m} 2$ \\
\hline 5 & $\begin{array}{l}\text { Mooring Basin } \\
\text { depth }\end{array}$ & $3000 \mathrm{DWT}=6,5$ & $6,5 \mathrm{~m}$ \\
\hline
\end{tabular}

Based on the water facilities requirements at Branta Port, there must be a Visual Navigation Assistance or Sarana Bantu Navigasi Pelayaran (SBNP) suggestion. According to PM No. 25 of 2011 concerning Sailing Navigation Aids, it will be moved on land or on a Branta ship consisting of a light buoy. In addition, Branta Port development will also be equipped with an electronic Navigation Support Facility (SBNP) consisting of a Global Positioning System (GPS) on Coastal Radio Stations, Ship Traffic Services, and Local Port Services.

\subsection{Branta Port Development Strategy}

Branta Port development strategies includes the needs for basic and supporting facilities obtained based on calculations according to the results of forecasting that have been done before. Development needs for the mainland are based on development phases, short term (5 years), medium term (10 years), and long term (20 years). The development of territorial waters is planned only for long-term phasing based on the specifications of the largest ships that will come to the port.

\subsubsection{Short-term Port Development Strategy} (2019-2024)

In the short-term port planning (5 years), development plans for the port dock and other land facilities are planned, which include the needs of warehouses and stock yard. Here are some development plans:

- Developing the pier length from the existing pier which has a length of $100 \mathrm{~m}$ to $186 \mathrm{~m}$.

- Construction of $183 \mathrm{~m}^{2}$ port warehouse for storage of goods to be sent or unloaded.

- Carry out maintenance on the port stacking field.

- Load and discharge equipment procurement in the form of forklifts or related loading and unloading equipment to maximize load and discharge production at the port.

- Make improvements to non-functioning port navigation system.

\subsubsection{Medium-term Port Development Strategy (2019-2029)}

In the medium-term development phase, Branta Port is focused on improving the causeway by adding $234 \mathrm{~m}$ of pavement in the causeway area. Proposed special access road for port interests to be built by the local government. Due to the existing conditions there are no waste storage facilities, the facility is also recommended to be carried out at the mid-term development stage.

\subsubsection{Long-term Port Planning Strategy (2019- 2039)}

In planning the development of Branta Harbor in the long term, several things are carried out, namely maintenance of port support facilities as well as the development of jetty and stacking yard facilities and warehouses in accordance with forecasting data that has been calculated.

From the three Branta Port development planning strategies, it can be seen that there are several small-scale development plans such as the 
development of port docks, warehouse construction, stacking field development and so on.

Table 12. Branta Port Facilities Development

\begin{tabular}{|c|c|c|c|c|c|}
\hline \multirow{2}{*}{ No } & \multirow{3}{*}{ Facilities } & Existing & Short Term & Mid Term & Long Term \\
\cline { 3 - 6 } & & 2019 & $(2019-2024)$ & $(2019-2029)$ & $(2019-2039)$ \\
\hline 1 & Pier Length & $100 \mathrm{~m}$ & $186 \mathrm{~m}$ & $186 \mathrm{~m}$ & $186 \mathrm{~m}$ \\
\hline 2 & Warehouse & - & $146 \mathrm{~m}^{2}$ & $146 \mathrm{~m}^{2}$ & $183 \mathrm{~m}^{2}$ \\
\hline 3 & Cargo Yard & $98 \mathrm{~m}$ & $73 \mathrm{~m}^{2}$ & $73 \mathrm{~m}^{2}$ & $91^{2}$ \\
\hline
\end{tabular}

\section{CONCLUSION}

From forecasting analysis of ships call and ship loading and discharge flows at Branta Port, it can be seen that the number have fluctuating pattern. Where the pattern has a bearing on the productivity of salt in Madura. Branta Port development strategies divided into three parts, the short term (2019-2024), the medium term (20192029), and the long term (2019-2039) strategies. The direction of the Branta Port development strategy is to fulfill the port's role as a core port for boosting the economic sector and supply chain logistics from Pamekasan Regency and Madura. Especially in the leading sectors of salt, livestock and tobacco. While the development priorities includes the development of port docks, warehouse construction and repair of the stockpile field, adding some navigation systems, repairing the port causeway, construction of waste treatment facilities, procurement of load and discharge equipment. Branta Port development also has a positive environmental impact, which is expected that the construction of waste handling facilities can minimize port waste water pollution to the area around the port.

\section{REFERENCES}

Pettit, S.J., Beresford, A.K.C. 2009. "Port development: from gateways to logistics hubs." Maritime Policy \& Management: The flagship journal of international shipping and port research 36253.

Slack, N., Chambers, S., Johnston, P.R. 2007. Operations management. Pearson Education.

The Overseas Coastal Area Development Institute of Japan. 1999. Technical Standards and Commentaries of Port and Harbour Facilities. Tokyo: Daikousha Printing Co., Ltd.

Triatmodjo, Bambang. 2009. Port Planing Yogyakarta: Beta Offset Yogyakarta.

Van den Berg, R., De Langen, P.W. 2011. "Hinterland strategies of port authorities: A case study of the port of Barcelona." Research in Transportation Economics 33 6-14.

5. 